\title{
Continuing Professional Development: Understanding the Perceptions of Higher Institution Lecturers in Anambra State, Nigeria
}

\author{
Patrick, Ogechukwu Blessing \\ Faculty of Education, Department of Education Leadership and Management, \\ Southwest University, \\ No.2 Tiansheng Road, Beibei District, Chongqing, 400715, P.R China \\ E-mail: patrickblessingogechukwu@gmail.com \\ Okafor, Miracle Uzochukwu \\ Department of Chinese Studies, Nnamdi Azikiwe University, Awka \\ P. M. B. 5025, Awka, Anambra State, Nigeria \\ E-mail: mu.okafor@unizik.edu.ng
}

\begin{abstract}
This paper, which drew on quantitative and qualitative data, was mainly aimed at examining the perceptions of higher institution lecturers in Nigeria concerning the effectiveness, facilitators, and inhibitors of CPD activities provided by their higher institutions and/or the Ministry of Education. The researchers employed and adapted the data collection instrument by Sywelem \& Witte (2013) designed to collect data on perceptions of teachers regarding professional development opportunities and activities that exist in Saudi schools. The interview questions were designed by the researchers to access lecturers' evaluation of the professional development programs and activities in their institutions. Research survey was sent to lecturers in 3 representative higher institution in Anambra state, 213 survey responses and 15 interviews were received and analyzed. Results showed that the participants did recognize the importance and usefulness of CPD activities and expressed how CPD activities has impacted them as professionals. Lecturers expressed their expectations with regards to program content, time management, financial and moral sponsorship and support, etc. It was recommended that for lecturers to be effective at their jobs in the higher institution system, their professional development and inservice training programs must be given good attention by the management.
\end{abstract}

Keywords: Lecturers' perception, Continuing Professional Development, In-service training, Nigerian higher institutions.

DOI: $10.7176 / \mathrm{JEP} / 12-20-05$

Publication date:July $31^{\text {st }} 2021$

\section{Introduction}

Professional development (PD) is one of the important issues for lecturers in higher education. Higher education quality is heavily influenced by lecturer quality and the professional development process has a significant positive impact on teacher quality (Xu, 2015; Xia, Gao, \& Shen, 2017). Recent researches suggest that lecturers need longer and sustainable professional programs to develop new knowledge and make good, observable progress (Wati, 2011). Change is one of the constants in life and one of the areas which require urgent attention and change to achieve the goal of improving educational quality is improving the quality of teachers in schools and higher institutions (Federal Ministry of Education, 2014). The latest policy on Nigeria's National Teachers' Education (FME, 2014) emphasized greatly on supporting and funding the continuing professional development for teachers. The sixth, seventh and eighth principles of the policy stated that 'for teachers to learn well, teacher educators must be sufficiently trained and capable of imparting and modeling desired knowledge, skills and attitudes'; 'If teachers are to stay motivated, they must have opportunities for continuing professional development, advancement, and improvement in their chosen career'; 'Like all professionals, teachers must constantly upgrade their knowledge and skills if they are to remain relevant in a rapidly changing world' respectively (FME, 2014, p14-17). However, more often than not, the lopsided implementation of policies or the total failure to effectively bring into practice already stated public reforms has hindered national development in many ways.

Udoh-uwah \& Etim (2018) noted that to produce quality graduates with employability skills, abilities, and competencies to harness the available resources and solve practical problems in Nigeria, the university system must be efficient. The efficiency of the University system is greatly anchored on the competence of the academic staff which is dependent on their professional development because training and development play a vital role in the efficiency of the organizational system and the effectiveness of every personnel (Falola et al. 2014). In the University system, lecturers' professional development is encouraged through re-training programmes, 
mentorship, seminars, research publications, conferences, symposiums, inaugural lectures, Communication and Technology Gadget utilization, and so on (Adeyemi, 2011; Udoh-uwah \& Etim, 2018). As good as these programmes were and are, it has been observed that they tend to not be 21 st century oriented as they may not be inquiry-based kind of training, which should make teachers and educators discover knowledge for better facilitation of meaningful learning in the classrooms (Kambona, 2019). In Nigeria, different terms are often used as synonymous to professional development, they are academic staff training and development (Oyebade, 2008; Ozurumba \& Amasuomo, 2015; Suleiman, 2015; Akomolafe \& Belo, 2019), in-service training (Iyunade, 2011; Nwaubani et al., 2016) and capacity building (Akuegwu et al., 2013; Bakare et al., 2018).

\subsection{Problem statement}

Globally, professional development and service delivery of academic staff has been recognized as essential in the realization of the core objectives of universities (Nabunya et al, 2019). Academic staff is expected to be professional in conduct, effective in relevant teaching content, preparing before teaching, using appropriate teaching methods, assessing learners' resources, and conducting research (Walters \& Openjuru, 2016). Teachers' professional development in Nigeria is not impressive in terms of availability and accessibility and the ones that are available are haphazard, unattractive, and non-continuous. The programs are more like a sequence of unconnected episodes rather than connected, sustained, continuous and intensive programs. Akuegwu et al. (2013) noted that the capacity-building efforts of universities in south-south Nigeria have been hampered by institutional inadequacies which may include a lack of qualified facilitators, chief among which is the paucity of funds. The programs often reflect budget constraints, volatility, and logistical challenges. These programs may often reflect policymakers' and donors' misunderstandings about who lecturers are, what they do, and how they should learn. It may not take into account the tenets of adult learning that may occur only on a short-term basis and be disconnected from policies around academic staff recruitment, assessment, retention, support, and compensation. As expected, lecturers perceive these PD programmes as being of low quality and completely irrelevant - something to be endured rather than embraced, as the contents of the capacity building or development programs do not reflect and concur with the lecturers real working environments resulting in a poorly designed professional development programme thereby arousing the need to examine how these lecturers perceive their continuing professional development programs. Besides the problem of poor logistics, some other observed challenges include professional misconducts and poor service delivery of academic staff irregular attendance of classes and extension of lectures till the eve of examinations, poor assistance of students working on their projects and dissertations, lecturers' lack of proficiency in the use of ICT gadgets, poor lecturer-student relationship, etc. which depicts the ineffectiveness of CPD in the higher institutions and makes it a matter of concern (Akuegwu et al., 2013).

Nevertheless, Yusuf et al. (2013) reported that certain implemented capacity-building activities like the ICT training for lecturers have been successful and effective. The findings indicated that ICT activities have significantly impacted higher educational practice in Nigeria, and it is envisaged that such impact would undoubtedly grow considerably in years to come, and if observed inhibitors and hindrances are properly ameliorated, ICT would become a strong agent for change in many tertiary educational institutions in Nigeria (Yusuf et al. 2013). On the same note, Ujumadu (2020) reported that ICT capacity building activities at a key and federal polytechnic in Anambra state which was aimed at helping lecturers to keep abreast of the modern technology in teaching and learning, as well as acquaint them with the new technology and growing trend to integrate ICT into education have empowered lecturers for greater productivity. Seeing the different observations on lecturers' professional development, the researcher moves to investigate the perceptions of the CPD by Nigerian lecturers and the possible facilitators and inhibitors to the effectiveness of the CPD programs in three tertiary institutions in Anambra, a university, a polytechnic, and a college of education.

\subsection{Purpose the Study}

The purpose of this study was to examine the perceptions of higher institution lecturers in Nigeria concerning the effectiveness, facilitators, and inhibitors of CPD activities provided by the higher institutions and/or the Ministry of Education. Additionally, the study was designed to determine whether the professional development programs are providing valuable knowledge and skills to the lecturers to promote students' achievement and improve school climate. The study was also designed to determine if there are differences between male/female lecturers as well as less/more experienced teachers regarding their perceptions of CPD activities and programs. This study attempts to achieve these aims by answering the following research questions:

- What are the perceptions of lecturers at the higher institutions on the usefulness of CPD programs and activities in Nigeria?

- What are the perceptions of lecturers at the higher institutions about the facilitators and inhibitors of their CPD programs and activities in Nigeria?

- Are there significant differences between the perceptions of male and female lecturers regarding the 
usefulness, facilitators, and inhibitors of their CPD?

- Are there significant differences between the perceptions of the less experienced and more experienced lecturers regarding the usefulness, facilitators, and inhibitors of their CPD activities and programs?

- How did lecturers evaluate the CPD activities attended and were there observable changes in individual abilities?

This research contributes to understanding lecturers' perceptions of professional development, the facilitators and inhibitors of CPD programs and activities. This research is significant for lecturers and higher institutions in Nigeria, especially the institutions under study, policymakers and training associations will necessarily find the information and data gathered by this research useful for future and subsequent planning of CPD activities, and also important to higher education students whose academic and research abilities and relationship with lecturers will improve. The researcher also observed that Professional development studies on Nigerian lecturers are relatively undeveloped and understudied, therefore this study intends to add to the body of knowledge and improve insight.

\section{Literature Review}

Professional development as an area of research has been receiving a significant increase in the level of interest and support globally and it has been evidenced as imperative that teachers and educators receive professional development regularly and systematically (Adagiri, 2014). One aspect of global collaboration in the higher education arena is professional development for university leaders on campuses abroad (Cook, 2014, p.121). Several pieces of research have also proved that teacher professional development has an impact on teachers' beliefs and behavior, students' learning and also has had an impact on the success of educational reform (Xu, 2015; Xia, Gao, \& Shen, 2017). Professional development broadly refers to the development of an individual/staff in his or her professional role and specifically, teacher development refers to the professional growth a teacher attains and achieves as a result of "gaining increased experience and examining his or her teaching systematically" (Villegas-Reimers, 2003, p11).

According to Rosmaladewi \& Abduh (2017) \& Abduh \& Rosmaladewi (2018), professional development is a way of developing a high level of human resources so that graduating students can be human capital for organizations and assets to their societies, provide opportunities for collaborative work among lecturers and open up intercultural understanding. Desimone (2011) highlighted that professional development aims to improve the knowledge and skills of lecturers so that they can perform at the highest possible level they can perform. According to Ogunyinka et al., (2015), teacher education comprises professional education of teachers towards the acquirement of attitudes, skills, and knowledge considered needful to make them resourceful, efficient, and effective in their work, according to the need of a given context at a given time. Teacher education includes training and/or education that takes place before the commencement of service (pre-service) and during service (in-service or on-the-job) (Adagiri, 2014).

Every society requires adequate human and material resources to improve its social organization, preserve the culture, enhance economic development and reform the political structures (Ogunyinka et al., 2015). Capacity-building programmes have been adjudged to be critical factors in Nigerian universities, culminating in their positions as major determinants of lecturers' professional advancement (Akuegwu et al, 2013). Apart from gaining pedagogical and content knowledge, lecturers' participation in the programmes enhances capacitybuilding effectiveness in universities. It transforms role performance abilities and skills of lecturers in such a way and manner that they meet and fit adequately in the challenges of their jobs. Without it, a missing gap evolves whereby universities become shadows of themselves (Akuegwu et al., 2013)

\subsection{Researches on lecturers CPD in Nigeria}

Ekpoh et al., (2013) empirically revealed that evaluating teachers in the terms of knowledge of the subject matter, classroom management, the methods and evaluation of students' work, teachers who participated in staff development programs were found to be more effective in their job performance than those who did not. Amadi \& Promise (2013) identified that in-service training courses, curriculum change, innovation in teaching methodologies, and provision of quality professional growth and development enhance teachers' and lecturers' service delivery. Akpan (2014) researched to establish the influence of ICT competence on lecturers' Job Efficacy in two Nigerian universities. The research employed a descriptive survey research design to examine a population of 1795 lecturers from the two universities in the Cross River State. There was a random selection of 500 participants (187 females and 313 males) lecturers were randomly selected as a sample for the study. The result of the study showed ICT Competence does not differ significantly among participating lecturers based on gender, and that level of ICT competence significantly influences their job efficacy in classroom instruction, research/publication, communication, and record-keeping. Suggestions included encouraging staff to reflect on how they teach and offering greater access to learning how to teach (Olelewe \& Amaka, 2011; Akpan, 2014).

Garuba (2007) stressed that an effective CPD must be school/institution-based, sustainable, cost-effective, 
and affordable, have a good monitoring and implementation system. School-based CPD is the most realistic and allows for needs analysis of the teacher and learner to be incorporated into the programme since it is schoolspecific and suggests that proper evaluation and constant monitoring are important in determining the effectiveness of CPD. Akuegwu et al. (2013) noted that the capacity-building efforts of universities in southsouth Nigeria have been hampered by institutional inadequacies, chief among which is the paucity of funds. This has negatively affected institutional provisions for lecturers' participation in conferences, seminars, workshops, and ICT training. The consequence of this is low research productivity among lecturers, professional misconduct, and poor student guidance during dissertations, etc. In that these programmes play a vital role in enhancing research capacity, poor funding usually results in lecturers' poor participation in capacity-building programmes and to a greater extent to a poor ranking of the tertiary institutions in the world.

Nevertheless, Yusuf et al. (2013) reported that certain implemented capacity-building activities like the ICT training for lecturers have been successful and effective. The findings of the research indicated that ICT activities have significantly impacted higher educational practice in Nigeria, and it is envisaged that such impact would undoubtedly grow considerably in years to come, and if observed inhibitors and hindrances are properly ameliorated, ICT would become a strong agent for change in many tertiary educational institutions in Nigeria (Yusuf et al. 2013). On the same note, Ujumadu (2020) reported that no fewer than 100 staff of the Federal Polytechnic Oko, Anambra State, have undergone training on Information and Communication Technology (ICT). Capacity-building activities at this key and federal polytechnic in Anambra state, which was aimed at helping lecturers to keep abreast of the modern technology in teaching and learning, as well as acquaint them with the new technology and growing trend to integrate ICT into education, has empowered lecturers for greater productivity. Lecturers are improving and adjusting to the use of computers in preparing examinations, storing data, and doing research.

\subsection{International researches on lecturers $C P D$}

There are several kinds of research on lecturers' professional development that emerged in the past years. Chism et al. (2010) noted that professional development, especially university faculty development, is a growing priority in many parts of the world. As higher education expands across the globe, Lee et al. (2013) pointed out that its success depends to a great extent on quality assurance and professional development for university faculty and administrators is a key step in fostering quality. Leibowitz et al. (2015) investigated the access to professional development involving 18 lecturers from eight South African universities. The findings pointed out that increased regular accessibility to professional development programs for lecturers' results in increased benefits in terms of knowledge updates and greater impacts on the quality of teaching and learning. Regarding the planning of international professional development programmes, it is advised that any international professional development programmes, to serve its participants well, should grow from an understanding of the participants' context and respond to their specific interests and expressed needs (Carew et al. 2008; Lee et al. 2013).

Rosmaladewi et al. (2020) qualitatively explored the experiences of 9 English lecturers on Professional Development in 3 Indonesian Polytechnics, the findings attest that lecturers believe that PD to be one of the important alternative mediums for skill and knowledge development. The lecturers reported limited opportunities to grow professionally and considered themselves as second-class citizens and were encouraged to improve their knowledge and skills in their efforts and programs without distracting the teaching and learning process occurring in the three polytechnics. Rosmaladewi et al. (2020) noted that there are several important reasons why PD is fundamental for lecturers in polytechnics. The reasons include: a) they can update their knowledge and skills so that they can perform the best quality of teaching; b) they can update the current trend of technologies so that they can use them for teaching, and c) they open up the opportunities to grow themselves personally and professionally.

\subsection{Relevance of CPD for lecturers}

Professional development can be defined as the activities aimed at acquiring new knowledge and skills for effective job delivery. Padwad \& Dixit (2011) defined Continuous Professional Development as a planned, continuous, and lifelong process whereby teachers try to develop their personal and professional qualities, and to improve their knowledge, skills, and practice, leading to their empowerment, the improvement of their agency and the development of their organizations and their pupils.

The primary relevance of CPD is to the lecturers. CPD in the higher institution is aimed at meeting the professional needs of educators, enhancing their career prospects, and supporting them in preparing for future challenges. Engaging in CPD will help to equip teachers with relevant skills for instructional delivery, update their knowledge and expose them to new methods and materials to meet the dictate of modern realities of the job. CPD is also relevant to improve students' abilities and performance. This is because CPD focuses on bringing about change in the lecture room. Another relevance of CPD is to the institution. As teachers are considered as 
an asset to their schools; their professional development is imperative in determining the standard and quality of schools. Successful schools are perceived as those which recognize that building effective teacher-teacher, and teacher-student connections can only be enacted if teachers themselves are routinely engaged in continuous learning.

Constant changes in the working conditions of teachers together with an increased impact of information and communication technologies led to the need for teachers to engage in professional development activities (Sywelem \& Witte, 2013). Professional development is at the core of educational improvement and teachers (lecturers) are indispensable stakeholders, playing key roles, in bringing about the necessary changes (Patrick, 2020), therefore, it is of paramount importance that lecturers participate in training and development programs to become ready to accept changes and implement appropriate methods in the lecture rooms (Roux \& Ferreira, 2005).

Another need for the continuous professional development of higher institution lecturers is that higher institutions face complex and dynamic changes and challenges. These challenges may be associated with adult teaching and learning, professional conduct, and teaching styles that are towards a student-centered paradigm. Continuing professional development is important to lecturers' personal lives and career development and focuses on fostering individual competence to enhance practice and facilitate dynamic changes in education (Blandford, 2000; Sywelem \& Witte, 2013). Parkes \& Stevens (2000) stated that professional development activities can also influence teacher job satisfaction and teachers' subsequent plans to remain in the teaching career. Furthermore, professional development activities are acknowledged to be centrally important in maintaining and enhancing the quality of teaching and learning in schools as they help teachers to be more confident, capable, and fulfilled (Darling-Hammond \& Baratz-Snowden, 2005).

Teachers and lecturers' professional development can come in many forms. They may include workshops, mentoring, collaborative activities, action research, conferences, seminars, leave/permission to further education, funding for lecturer research and publication, moral and financial support for international conference presentations, etc. These CPD activities can be sourced internally within a school, external sources, and school networks. If the quality of teaching in Nigeria will be improved, several elements in this regard, including lack of skill, preparation, and information on the part of lecturers, poor knowledge of ICT will be addressed and these are important content and elements that make professional development.

\subsection{Facilitators and inhibitors of lecturers' $C P D$}

Several recent pieces of literature noted the lack of funding for staff development needs and argued that several standardized CPD does not take into account a teaching staff's existing knowledge, experiences, and needs (Akuegwu et al., 2013). Several researchers also noted the lack of autonomy as an inhibitor to the CPD of lecturers and teachers (Sywelem \& Witte, 2013). Along with a lack of autonomy, excessive workloads increases fatigue and reduces time to pursue CPD after work hours, unsupportive working conditions at school, and unavailability of relevant CPD course. It has been observed that many institution-based staff development activities do not assist lecturers in enhancing their ability to improve student learning. Teachers and lecturers tend to teach in the way that they are taught so if teachers/lecturers do not receive professional development opportunities, they will continue to teach the same as they have always taught, without questioning their practices (Snow-Renner \& Lauer, 2005).

Inadequate funding has been a fundamental issue in teacher education which reflects in other areas including quality of training facilities, availability of resources, salaries and this is attributable to low budgetary allocation to education, (Akuegwu et al. 2013) poor management, and lack of accountability especially in some of the government institutions. The quality of training programmes has been a huge concern as studies indicate pertinent issues including poor supervision and assessment and inconsistency in the depth of training in different parts of the country (Ferman, 2002; Usman, 2006). The strategic plan on Nigerian education affirms that the system and process of training and developing teachers is seriously deficient and very weak teachers are produced (FME, 2014). Lack of awareness of opportunities can serve as an inhibitor to CPD participation, working conditions, school culture, and lack of support from management also affect teachers' participation in CPD (Paymaster et al., 2014).

Muijs et al. (2004) stressed that effective CPD should address the specific needs of educators and highlighted that CPD will have a positive impact only when it is in congruence with lecturers' context. Some factors were identified to be associated with institutional leadership that led to successful CPD for lecturers and educators within an institution which can serve as a framework for academic staff professional development (Wall, 2013). These factors included belief in the overall purpose of CPD; ensuring that school policies support new teaching strategies; and creating an atmosphere that encourages research, innovation, and experimentation. Other important strategies included providing educators with time and opportunities to meet and share ideas; not overloading them with work; ensuring sufficient availability of resources. Availability of CPD opportunities is a necessary condition, however, it is not sufficient as teachers' willingness and interest in participation is essential. 
It is widely asserted that low teacher motivation is reflected in low standards of professional conduct, especially in developing countries (UNESCO, 2011). Poor working conditions, etc. invariably affect their enthusiasm towards professional development (Bennell \& Akyeampong, 2007).

\section{Methodology}

3.1 Instrumentation

This paper drew on quantitative and qualitative data. The researchers employed and adapted the data collection instrument by Sywelem \& Witte (2013) designed to collect data on perceptions of teachers regarding professional development opportunities and activities that exist in Saudi schools. The adapted survey consisted of two sections. The first section included questions to retrieve demographic information about participants, such as the type of institution in which they work, their gender, and experience in teaching. This section was designed to collect information that will help the researchers to have a deeper understanding of the respondents and the trends that emerged from the study. The second section of the survey consisted of 20 Likert-type items. This section was designed to address teacher's perceptions regarding two main themes: the usefulness of CPD and the facilitators/inhibitors of CPD activities in Nigerian higher institutions. Cronbach Alphas were calculated for the instrument responses and calculated for each scale. The Cronbach Alpha coefficient for the entire instrument was $(\alpha=0.80)$. The Cronbach Alpha coefficients for the items ranged in value from 0.77 to 0.79 for each scale. These reliability coefficients were determined to be sufficiently reliable. The qualitative data was gotten from interviewing lecturers at 3 higher institutions in Anambra state. As the research believed that the 3 higher institutions are fine representatives of the other higher institutions within the state, 15 lecturers were interviewed from all three, five from each institution. The interview questions were designed to access lecturers' evaluation of the professional development programs and activities in their institutions.

\subsection{Sample Selection and Data Analysis}

The population of this research includes higher institutions in Anambra with purposive sampling of 3 higher institutions (one university, one polytechnic, and one college of education). These schools are popular higher institutions in Anambra and can stand as a representative of other higher institutions within the state. A representative sample of 213 participants from the 3 tertiary institutions was selected. The data collected through the questionnaire were analyzed using descriptive statistics to determine the percentages, means, standard deviations, also an independent sample t-test technique, and one way ANOVA technique to show frequencies and $\mathrm{P}$ values (significance). The table below provides the demographics:

Table 1: Demographics

\begin{tabular}{|l|l|l|l|}
\hline & Items & $\mathrm{N}$ & $\%$ \\
\hline \multirow{3}{*}{ Gender } & Female & 114 & 53.5 \\
\cline { 2 - 4 } & Male & 99 & 46.5 \\
\hline \multirow{3}{*}{ Experience } & Less than 10 years & 150 & 29.6 \\
\cline { 2 - 4 } & More than 10 years & 63 & 70.4 \\
\hline & University & 120 & 56.3 \\
\cline { 2 - 4 } & Polytechnic & 63 & 29.5 \\
\cline { 2 - 4 } & College of Education & 30 & 14.08 \\
\hline Total & & 213 & 100 \\
\hline $\mathrm{N}=213$ & & & \\
\hline
\end{tabular}

\section{Results}

The quantitative findings of this study are presented in two sections. The perception of lecturers concerning the usefulness of the CPD activities in which they participated and the facilitators \& inhibitors of those activities were explored and discussed. The results of lecturers' perceptions of the value of the CPD activities and the facilitators \& inhibitors of those activities are summarized in Tables 2, 3, and 4. For discussion purposes, "strongly disagree" and "disagree" were grouped, as were "strongly agree" and "agree". Seven statements in the survey questionnaire were designed to assess lecturers' perceptions of the usefulness. 
Table 2: Lecturers' Perceptions Regarding the Usefulness of CPD Activities

\begin{tabular}{|c|c|c|c|c|c|c|c|c|}
\hline Statements & & SA & A & D & SD & Mean & SD & Attitude \\
\hline \multirow{2}{*}{$\begin{array}{l}\text { 1. Professional Development programs provide } \\
\text { lecturers with new knowledge, skills, and } \\
\text { understanding for their staff development activities. }\end{array}$} & $\mathrm{N}$ & 123 & 84 & 6 & & \multirow[b]{2}{*}{1.45} & \multirow[b]{2}{*}{.553} & \multirow[t]{2}{*}{ Agree } \\
\hline & $\%$ & 57.7 & 39.4 & 2.8 & & & & \\
\hline \multirow{2}{*}{$\begin{array}{l}\text { 2. Professional development changed the way you } \\
\text { teach in the classroom. }\end{array}$} & $\mathrm{N}$ & 90 & 111 & 12 & & \multirow[t]{2}{*}{1.63} & \multirow[t]{2}{*}{.589} & \multirow[t]{2}{*}{ Agree } \\
\hline & $\%$ & 42.3 & 52.1 & 5.6 & & & & \\
\hline \multirow{2}{*}{$\begin{array}{l}\text { 3. Professional development activities which I have } \\
\text { attended are very useful in solving the difficulties that } \\
\text { I had in the classroom. }\end{array}$} & $\mathrm{N}$ & 114 & 90 & 9 & & \multirow[t]{2}{*}{1.51} & \multirow[t]{2}{*}{.580} & \multirow[t]{2}{*}{ Agree } \\
\hline & $\%$ & 53.5 & 42.3 & 4.2 & & & & \\
\hline \multirow{2}{*}{$\begin{array}{l}\text { 4. The training programs give the lecturers all the } \\
\text { necessary skills to be effective teachers. }\end{array}$} & $\mathrm{N}$ & 102 & 96 & 15 & & \multirow[t]{2}{*}{1.59} & \multirow[t]{2}{*}{.621} & \multirow[t]{2}{*}{ Agree } \\
\hline & $\%$ & 47.9 & 45.1 & 7 & & & & \\
\hline \multirow{2}{*}{$\begin{array}{l}\text { 5. Professional development activities provide ideas } \\
\text { and strategies that are helpful with classroom } \\
\text { management. }\end{array}$} & $\mathrm{N}$ & 114 & 90 & 9 & & \multirow[t]{2}{*}{1.51} & \multirow[t]{2}{*}{.580} & \multirow[t]{2}{*}{ Agree } \\
\hline & $\%$ & 53.5 & 42.3 & 4.2 & & & & \\
\hline \multirow{2}{*}{$\begin{array}{l}\text { 6. In-service activities are not necessary; teaching } \\
\text { experience helps lecturers more }\end{array}$} & $\mathrm{N}$ & 18 & 57 & 126 & 12 & \multirow[t]{2}{*}{2.62} & \multirow[t]{2}{*}{.722} & \multirow[t]{2}{*}{ Disagree } \\
\hline & $\%$ & 8.5 & 26.8 & 59.2 & 5.6 & & & \\
\hline \multirow{2}{*}{$\begin{array}{l}\text { 7. There are enough in-service activities/opportunities } \\
\text { available for higher institution lecturers. }\end{array}$} & $\mathrm{N}$ & 12 & 75 & 111 & 15 & \multirow[b]{2}{*}{2.61} & \multirow[b]{2}{*}{.705} & \multirow[t]{2}{*}{ Disagree } \\
\hline & $\%$ & 5.6 & 35.2 & 52.1 & 7.0 & & & \\
\hline
\end{tabular}

More than half of the survey participants indicated that participating in CPD activities helps lecturers to gain new knowledge and skills $(97.1 \%$ A or SA versus $2.8 \% \mathrm{D})$, and to change the way of their lecturing in the classroom $(94.4 \%$ A or SA versus $5.6 \% \mathrm{D})$, and to solve the difficulties that they had in classrooms $(96.1 \%$ A or SA versus $4.2 \% \mathrm{D})$, and to be effective lecturers (93\% A or SA versus $7 \% \mathrm{D})$ and that CPD activities provide lecturers with ideas and strategies that are helpful with classroom management $(95.8 \%$ A or SA versus $4.2 \%$ D). The following findings reflect that lecturers are hesitant about their consideration of the usefulness of CPD activities. More than half of the participants found CPD activities helpful, while the others did not. The majority of the participants $(64.8 \%)$ indicated that the in-service training activities were necessary and the majority of the respondents $(59.1 \%)$ also indicated that there were insufficient in-service activities/opportunities available for tertiary institution lecturers.

Table 3: Lecturers' Perceptions Regarding Facilitators/Inhibitors of CPD Activities (The Content and Design of CPD Activities)

\begin{tabular}{|c|c|c|c|c|c|c|c|c|}
\hline Statements & & SA & A & D & SD & Mean & SD & Attitude \\
\hline 8. The Professional development sessions are & $\mathrm{N}$ & 30 & 141 & 42 & & \multirow[t]{2}{*}{2.06} & \multirow[t]{2}{*}{.581} & \multirow[t]{2}{*}{ Agree } \\
\hline $\begin{array}{l}\text { instructed by presenters that are knowledgeable, } \\
\text { enthusiastic, and well organized }\end{array}$ & $\%$ & 14.1 & 66.2 & 19.7 & & & & \\
\hline \multirow{2}{*}{$\begin{array}{l}\text { 9. The learning climate of professional development } \\
\text { activities is collaborative, informal, and respectful }\end{array}$} & $\mathrm{N}$ & 9 & 177 & 27 & & \multirow[t]{2}{*}{2.08} & \multirow[t]{2}{*}{.403} & \multirow[t]{2}{*}{ Agree } \\
\hline & $\%$ & 4.2 & 83.1 & 12.7 & & & & \\
\hline \multirow{2}{*}{$\begin{array}{l}\text { 10. Professional development does take into account } \\
\text { lecturers' existing knowledge, experiences, and needs }\end{array}$} & $\mathrm{N}$ & 6 & 150 & 57 & & \multirow[t]{2}{*}{2.24} & \multirow[t]{2}{*}{.491} & \multirow[t]{2}{*}{ Agree } \\
\hline & $\%$ & 2.8 & 70.4 & 26.8 & & & & \\
\hline \multirow{2}{*}{$\begin{array}{l}\text { 11. Participants in Professional development activities } \\
\text { are involved in determining the topics and content. }\end{array}$} & $\mathrm{N}$ & 18 & 138 & 57 & & \multirow[t]{2}{*}{2.18} & \multirow[t]{2}{*}{.566} & \multirow[t]{2}{*}{ Agree } \\
\hline & $\%$ & 8.5 & 64.8 & 26.8 & & & & \\
\hline \multirow{2}{*}{$\begin{array}{l}\text { 12. The Professional development sessions are } \\
\text { planned with the school and system goals in mind. }\end{array}$} & $\mathrm{N}$ & 15 & 183 & 15 & & \multirow[t]{2}{*}{2.00} & \multirow[t]{2}{*}{.376} & \multirow[t]{2}{*}{ Agree } \\
\hline & $\%$ & 7.0 & 85.9 & 7.0 & & & & \\
\hline \multirow{2}{*}{$\begin{array}{l}\text { 13. Lecturers are allowed to provide feedback on the } \\
\text { professional development activities. }\end{array}$} & $\mathrm{N}$ & 15 & 180 & 18 & & \multirow[t]{2}{*}{2.01} & \multirow[t]{2}{*}{.394} & \multirow[t]{2}{*}{ Agree } \\
\hline & $\%$ & 7 & 84.5 & 8.5 & & & & \\
\hline \multirow{2}{*}{$\begin{array}{l}\text { 14. During training programs, lecturers are given } \\
\text { opportunities to share their ideas and experiences with } \\
\text { other lecturers. }\end{array}$} & $\mathrm{N}$ & 18 & 183 & 12 & & \multirow[t]{2}{*}{1.97} & \multirow[t]{2}{*}{3.75} & \multirow[t]{2}{*}{ Agree } \\
\hline & $\%$ & 8.5 & 85.9 & 5.6 & & & & \\
\hline
\end{tabular}

Table 4 shows lecturers' perceptions regarding the facilitators \& inhibitors of CPD activities. Statements 814 were designed to display the facilitation \& inhibitions related to the content and design of CPD activities. Most of the participants $(80.3 \%)$ agreed that the instructors of CPD sessions were knowledgeable, enthusiastic, and well organized. The majority $(87.3 \%)$ also agreed that the learning climate of CPD activities was collaborative, informal, and respectful, and during training sessions, lecturers are given opportunities to share their ideas and experiences with others $(94.4 \%)$, as well as to provide feedback on the professional development activities $(91.5 \%)$. Table 4 also demonstrates that most of the respondents believe that CPD activities took into account lecturers existing knowledge, experiences, and needs (73.2\%), and the planners of CPD sessions considered the school and system goals $(92.9 \%)$, and efforts are made to involve teachers in determining the topics and content of CPD activities (73.3\%). These findings reflect lecturers' views regarding the facilitators of 
CPD activities in Anambra state.

Table 4: Lecturers' Perceptions Regarding Facilitators/Inhibitors of CPD Activities (The Educational Climate at School)

\begin{tabular}{|c|c|c|c|c|c|c|c|c|}
\hline Statements & & SA & A & $\mathrm{D}$ & $\mathrm{SD}$ & Mean & SD & Attitude \\
\hline \multirow{2}{*}{$\begin{array}{l}\text { 15. School and faculty administration is supportive of } \\
\text { a lecturer's desire to grow professionally. }\end{array}$} & $\mathrm{N}$ & 18 & 147 & 48 & & \multirow[t]{2}{*}{2.14} & \multirow[t]{2}{*}{.540} & \multirow[t]{2}{*}{ Agree } \\
\hline & $\%$ & 8.5 & 69.0 & 22.5 & & & & \\
\hline \multirow{2}{*}{$\begin{array}{l}\text { 16. Administrators, Deans, and faculty leaders' } \\
\text { evaluation reports are very helpful in enabling } \\
\text { lecturers to grow professionally. }\end{array}$} & $\mathrm{N}$ & 9 & 114 & 84 & 6 & \multirow[t]{2}{*}{2.41} & \multirow[t]{2}{*}{.621} & \multirow[t]{2}{*}{ Agree } \\
\hline & $\%$ & 4.2 & 53.5 & 39.4 & 2.8 & & & \\
\hline \multirow{2}{*}{$\begin{array}{l}\text { 17. Lecturers at my institution can attend any } \\
\text { workshops, seminars, or courses as they would like. }\end{array}$} & $\mathrm{N}$ & 9 & 150 & 54 & & \multirow[t]{2}{*}{2.21} & \multirow[t]{2}{*}{.503} & \multirow[t]{2}{*}{ Agree } \\
\hline & $\%$ & 4.2 & 70.4 & 25.4 & & & & \\
\hline \multirow{2}{*}{$\begin{array}{l}\text { 18. Lecturers at my institution have the opportunity to } \\
\text { work together, observe each other in classroom } \\
\text { teaching, and give each other constructive feedback. }\end{array}$} & $\mathrm{N}$ & 9 & 102 & 90 & 12 & \multirow[t]{2}{*}{2.49} & \multirow[t]{2}{*}{.671} & \multirow[t]{2}{*}{ Agree } \\
\hline & $\%$ & 4.2 & 47.9 & 42.3 & 5.6 & & & \\
\hline \multirow{2}{*}{$\begin{array}{l}\text { 19. Lecturers receive informal evaluations of my } \\
\text { teaching performance from other lecturers and } \\
\text { colleagues. }\end{array}$} & $\mathrm{N}$ & 126 & 78 & 9 & & \multirow[t]{2}{*}{2.45} & \multirow[t]{2}{*}{.578} & \multirow[t]{2}{*}{ Agree } \\
\hline & $\%$ & 59.2 & 36.6 & 4.2 & & & & \\
\hline \multirow{2}{*}{$\begin{array}{l}\text { 20. Lecturers in my school have access to professional } \\
\text { publications. }\end{array}$} & $\mathrm{N}$ & 9 & 108 & 93 & 3 & \multirow[t]{2}{*}{2.42} & \multirow[t]{2}{*}{.059} & \multirow[t]{2}{*}{ Agree } \\
\hline & $\%$ & 4.2 & 50.7 & 43.7 & 14 & & & \\
\hline
\end{tabular}

Statements 15-20 on Table 4 were designed to display the facilitation/inhibitions related to the educational climate at school. Table 4 shows that more than half of the survey participants $(78 \%$ A or SA versus $22.5 \%$ D) indicated that the school administration was supportive for them to grow professionally, most of them $(57.7 \% \mathrm{~A}$ or SA versus $2.8 \%$ D) reported that they can attend workshops, seminars or courses as they would like, Administrators and supervisors' evaluation reports are very helpful in enabling teachers to grow professionally (57.7\% A or SA versus $42.2 \%$ ), lecturers have opportunity to work together, observe each other in classroom teaching, and give each other constructive feedback (52.1\% A or SA versus $47.9 \% \mathrm{D}$ or SD), lecturers receive informal evaluations of my teaching performance from other lecturers $(95.8 \% \mathrm{~A}$ or SA versus $4.2 \% \mathrm{D})$, lecturers have access to professional publications $(54.9 \%$ A or SA versus $45.1 \% \mathrm{D})$.

T-test was done to determine whether or not there are differences between male and female teachers regarding the usefulness of CPD. The results according to participants' gender are shown in Table 5. In this study, the rule according to Levene's test was employed, If $\mathrm{P}<0.05$, reject $\mathrm{H} 0$ and accept $\mathrm{H} 1$. The variances are significantly different. So we cannot assume they are equal. If $\mathrm{p}>0.05$, accept H0. This means that variances are not significantly different. So we can assume they are equal.

Table 5: Differences between Male/Female Teachers Regarding the Usefulness of CPD

\begin{tabular}{|l|l|l|l|l|l|l|l|l|}
\hline & Gender & $\mathrm{N}$ & $\mathrm{x}$ & $\mathrm{SD}$ & $\mathrm{df}$ & $\mathrm{F}$ & $P$ & Result \\
\hline $\begin{array}{l}\text { Usefulness } \\
\text { of CPD }\end{array}$ & Female & 117 & 1.85 & .630 & 69 & .873 & .482 & Not Significant \\
\cline { 2 - 5 } & Male & 96 & 1.84 & .620 & & & & \\
\hline
\end{tabular}

Table 5 demonstrates that there were no significant differences between the views of male and female lecturers regarding the usefulness of their CPD at df of 293 and .05 level of significance, and p-value $(.482)>$ 0.05 . This means that there were no significant differences between the male and female lecturers in terms of their views regarding the usefulness of their CPD.

Table 6: Differences between Male/Female Teachers Regarding Facilitators/Inhibitors of CPD

\begin{tabular}{|l|l|l|l|l|l|l|l|l|}
\hline & Gender & $\mathrm{N}$ & $\mathrm{X}$ & $\mathrm{SD}$ & df & $\mathrm{F}$ & $\mathrm{P}$ & Result \\
\hline \multirow{2}{*}{$\begin{array}{l}\text { Content and design of } \\
\text { CPD }\end{array}$} & Female & 117 & 2.01 & .440 & 69 & 2.445 & .323 & $\begin{array}{l}\text { Not } \\
\text { Significant }\end{array}$ \\
\cline { 2 - 8 } & Male & 96 & 2.15 & .457 & & & 306 & $\begin{array}{l}\text { Not } \\
\text { Significant }\end{array}$ \\
\hline
\end{tabular}

Table 6 demonstrates that there were no significant differences between the views of male and female lecturers regarding the facilitators/inhibitors of CPD related to content/design of CPD and the educational climate at school. For content/design variables, at df of 69 and .05 level of significance, and p-value $(.323)>$ 0.05 and the educational climate variables, at df of 69 and the p-value was $(.306)>0.05$.

Table 7: Differences between the Less/More Experienced Teachers Regarding the Usefulness of CPD

\begin{tabular}{|l|l|l|l|l|l|l|l|l|}
\hline & Experience & $\mathrm{N}$ & $\mathrm{x}$ & $\mathrm{SD}$ & $\mathrm{df}$ & $\mathrm{F}$ & $\mathrm{P}$ & Result \\
\hline \multirow{3}{*}{ Usefulness of CPD } & Less than 10years & 150 & 1.87 & .636 & & & & \\
\cline { 2 - 6 } & More than 10 years & 63 & 1.77 & .592 & 69 & .833 & .451 & Not Significant \\
\hline
\end{tabular}

Table 7 reveals that there were no significant differences between the less and more experienced lecturers regarding the usefulness of CPD. As shown in Table 7, at df of 69 and .05 level of significance, $\mathrm{F}=.833$ and $\mathrm{p}-$ value $(.451)>0.05$. This means that both the less and more experienced lecturers have the same views or 
perceptions regarding the usefulness of CPD.

Table 8: Differences between the Less/More Experienced Teachers Regarding Facilitators/Inhibitors of CPD

\begin{tabular}{|c|c|c|c|c|c|c|c|c|}
\hline & Experience & $\mathrm{N}$ & $\mathrm{x}$ & SD & $\mathrm{df}$ & $\mathrm{F}$ & $\mathrm{P}$ & Result \\
\hline \multirow[t]{2}{*}{ Content and design of CPD } & Less than 10years & 150 & 2.08 & .427 & \multirow[b]{2}{*}{69} & \multirow[b]{2}{*}{.516} & \multirow[b]{2}{*}{.586} & \multirow{2}{*}{ Not Significant } \\
\hline & More than 10 years & 63 & 2.05 & .519 & & & & \\
\hline \multirow[t]{2}{*}{ The educational climate } & Less than 10years & 150 & 2.32 & .598 & \multirow[b]{2}{*}{69} & \multirow[b]{2}{*}{.853} & \multirow[b]{2}{*}{.508} & \multirow{2}{*}{ Not Significant } \\
\hline & More than 10 years & 63 & 2.43 & .555 & & & & \\
\hline
\end{tabular}

Table 8 indicates that there were no significant differences between the views of the less and more experienced lecturers regarding the facilitators/inhibitors of CPD related to content/design of CPD and the educational climate at school. For content/design variables, at df of 69 and .05 level of significance, $\mathrm{F}=.516$ and $\mathrm{p}$-value $(.586)>0.05$, and Concerning the educational climate variables, $\mathrm{F}=.853$ and $\mathrm{p}$-value were $(.508)>0.05$, the perception of lecturers in Anambra state concerning factors that may facilitate or inhibit their professional growth are same and are not significantly different.

Thematic analysis was employed in analyzing the qualitative findings of this study to examine and interpret the qualitative data to understand what it represents. The participants of this interview were coded as follows:

Table 9: Demographics of Interview participants

\begin{tabular}{|l|l|l|l|}
\hline Institutions & Participant Codes & Work experience (Years) & Educational qualification \\
\hline & UNI 1 & 18 & PhD \\
\hline & UNI 2 & 2 & Masters \\
\hline & UNI 3 & 5 & Masters \\
\hline & UNI 4 & 2 & Masters \\
\hline & UNI 5 & 10 & Masters \\
\hline Polytechnic & POLY 1 & 5 & PGD \\
\hline & POLY 2 & 20 & PhD \\
\hline & POLY 3 & 10 & PhD \\
\hline & POLY 4 & 3 & Masters \\
\hline & POLY 5 & 8 & Masters \\
\hline College of Education & COE 1 & 10 & PhD \\
\hline & COE 2 & 12 & Masters \\
\hline & COE 3 & 20 & PhD \\
\hline & COE 4 & 5 & PGD \\
\hline & COE 5 & 3 & Masters \\
\hline
\end{tabular}

4.1 Relevance and sufficiency of CPD activities

COE3, who has worked for two decades at her institution and holds a Ph.D. agrees to the usefulness of the CPD activities for lecturers at her institution. She said,

"I cannot really place a number to the CPD activities I have attended home and abroad but I must say they have impacted the way I approached my students, especially the ones attended abroad. The CPD activities I attended were geared towards teaching students with different abilities, ICT training, Covid19 awareness, Training on guiding students during their dissertation, curriculum adjustment, etc."

UNI5 said: "CPD activities are aimed towards effective teaching and all-around progress of the academic staff, but usually, the reverse becomes the case here. I cannot tell where it goes wrong, planning or implementation." Poly1 with an indifferent tone doesn't think the CPD activities he has attended in his institution have made any difference in his abilities to teach or relate with the students in any way. He continued, "I've attended $P D$ programs on ICT training and educational development. It's just a personal view, I cannot speak for others. I have a stronger preference for staff meetings because they are particular and focused on departmental difficulties and challenges, not some randomly picked up issues"

Poly4: I like to attend CPD activities. I find them useful for me as a young lecturer. It affords me the opportunity to learn, unlearn and relearn things needed to be better, and to do better.

COE3, UNI5, and POLY4 made important points by saying that they have attended a couple of CPD activities practiced in their institutions which were useful and impacted them as lecturers. POLY1 gave the impression that even while there has been a couple of activities held in his school and department, he doesn't think the activities improve his abilities in areas he needed most. UNI4, a young lecturer from a university, appraised the CPD activities at her:

UNI4 said "This staff training and in-service training and professional development courses are all very necessary because when new lecturers are employed, they are just new and have no experience whatsoever. What a lecturer did as a first degree has usually nothing to do with teaching. These staff training and in-service training equip novice teachers to be able to handle students because trust me, lecturing in Nigeria is not easy. So 
I think all these training courses are very necessary and important. Because of the covid19 pandemic, we've not had lots of training activities where we get to stay together for a long time. But this year, I'd say we've had like, for us, 3 to 4 hours of Staff, training seminars, workshops, and orientation programs. While I can't say I like attending all PD programs, I would say they are okay and good." I would also say I don't think they provide enough training activities for lecturers in my institution because I have a friend who is working outside the country and over there, they have a lot of activities, it's almost like every month, they have lots of training activities to go and improve oneself and things like that. But in Nigeria so far so good. I've not seen much really, especially at (mentions name of institution), I don't think we have a lot of training activities.

UNI4 also noted that even though the provided activities are wonderful, there weren't sufficient programs available for teachers and lecturers in Nigerian institutions to attend. A number of authors confirm that a good CPD Programme for lecturers must aim to enhance competence and impact upon teaching and classroom practice (Thurston, Christie, et al, 2008). It is also important that the empowerment and training programmes generate lasting learning experiences.

4.2 Impact on professional practice and Lecturers' expectations

Poly 5 and Poly 3 both recalled the compulsory ICT sessions held for the lecturers and staff at their institution as the school transitioned from writing exams with paper and pen to Computer Based Test (CBT). They both used the word "intensive" and collaborative. During the course of the events, participants shared their experiences and asked practical questions to which they received practical answers. The training was important as the staff and lecturers ought to be aware of the mode of questions to ask and how to score students. The lecturers were trained to use the computer and this enabled them to improve on themselves as professionals.

Uni 3 said, "I haven't been involved in deciding the content of my faculty's CPD activities, I would really appreciate if I will be asked what I think, at least once in a while, being the consumer of the event contents (laughs). Usually, when I do not understand the purpose and relevance of a program, I find it to be timewasting." COE2 and COE4 also used the word "time-wasting" to describe some of the CPD activities in their institution in which they could not relate with.

UNI4 asserted, "I think the main aim of the PD activities is to equip lecturers with necessary skills to become an effective lecturer but sometimes, I feel most of the activities are not really is needed. For example, you tell me, okay, I know this is like the Covid19 period. Fine and then the school keeps on creating Covid19 awareness activities for lecturers, I feel it's not necessary at this point, I think we need more than that.

During staff training activities, we were taught how to lecture, create a curriculum, and make adjustments based on our students' academic needs. We were also taught how to create an effective timetable and study plan which is geared towards students learning. Initially, when I began lecturing, I didn't know how to deal with all these, and most times in class, you would have a course with close to 70 students. It's can be overwhelming. You know, when you get to the class, and the students are all talking at once, it was, really, really stressful during my first months of lecturing. But there was this activity, that was organized by our school and I discovered after attending that the activity was one of the in-service training activities. The speaker in charge spoke a lot about how to manage your class, how to create an adjustable, study plan, and timetable which a lecturer can use in class and also your curriculum for this semester, how to structure it in such a way, you able to cover up, what you are supposed to teach in a semester and also how to deal with students.

This activity covered both lecturers' physical needs and emotional needs. Seriously after attending that in-staff training activity, God! It helped me. And so anyway some staff training activities are helpful because a lot of people, especially the new ones coming to join the profession, there a lot of things they don't know. There are lots of things which they can't deal with on their own. Therefore I think these activities are just so helpful. I think these kinds of PD activities are very important and more important than some other activities."

Lecturers expect to be part of the decision-making of the training topics and they expect that event planners will be keen on time management. UNI4 mentioned that "Poor time management just gives off this negative vibes so next time I would not be interested in wanting to attend". CPD programs should be structured in such a way as to accommodate the already busy schedules of lecturers and to avoid causing more stress and burnout. CPD programs should be brief and fun, and with lasting experiences which will make lecturers look forward to subsequent events. Also, it should be noted that there is more to the lecturers' lifestyle besides academics. Events to boost an individual lecturer's personal life, health and well-being should be discussed too.

4.3 Sponsorship and Support

UNI1 said that if education had its rightful place in Nigeria, professional development will be highly sought after among the teaching staff, and education will be at the centre of major sponsorships. According to him,

"The society looks down on teachers. It's even quite easier for lecturers. With little or no financial support, lecturers will find it hard to have access to meaningful paid professional development program"

When presented with the same questions of what ideas will make staff training activities more effective so 
lecturers will develop professionally, COE1 and COE5 mentioned “sponsorship" as a factor that isn't always considered positively. They opined that it does not speak well of an institution when teachers are not encouraged to improve on themselves. "Teaching is an intellectual job", COE5 said and the PD programmes serve as sharpeners of teaching abilities.

Uni 2: "So far, I haven't really benefited from co-lecturers support, and it's important. I just know that my faculty and department administration support lecturers to work hard to become the best we should be. For example, I have my master's degree, the department keeps encouraging me to get my Ph.D. I should write and publish papers, these are things that will be useful in the future towards my academic growth. So I think the faculty and department are really interested in our well-being...like our professional well-being so they encouraged us to do a lot of things, even to attend conferences abroad. The department provides us access to professional journals and publications. We also have a lot of online Zoom meetings with well-known lecturers and professors from other universities where they come to talk to us about how to boost our academic roots. So, I think it's, really, really been helpful. I think lecturer-lecturer collaboration and mutual support are more of what we should encourage in our higher institutions.

Actually, I'm happy with the activities that are provided for lecturers, but most times I feel we should not be forced to attend all activities. I think a lecturer should be allowed to choose to attend based on his individual or career needs because there are different kinds of activities. If a lecturer isn't good in a particular area, he can be advised to attend certain activities that can help him/her, and not being forced to attend all activities. I know some people might disagree with my point of view, but I think it's better to go for what you feel, you're going to get value out of and not be forced to attend every activity."

Building a lecturer-lecturer peaceful environment and co-existence is key to developing a healthy culture in a department or faculty where lecturers have opportunities to share their ideas and experiences with other lecturers and give/receive feedback on their progress without fear. This is strong means of support. Lecturers can also feel seen, important, and supported when their views are considered valid in the decision-making of training themes and facilitators. Lecturers, especially when they are presenters, would want to be sponsored to CPD programs (conferences, seminars, workshops) in big cities and abroad where they can meet with staff and lecturers from other high-performing backgrounds and exchange information. Sponsorship on research paper publication when the institution and faculty of lecturer will be on the peer-reviewed journals can be considered as a viable means of support for lecturers.

\section{Conclusions, Discussion and Recommendations}

One of the important findings of this study was that the participants did recognize the importance and usefulness of CPD activities. Almost half of them believed that the in-service training activities helped get new knowledge and skills, solve the difficulties that they had in classrooms, and providing them with ideas and strategies that are helpful with classroom management, guiding students during the dissertation, curriculum adjustment to the students' academic needs, etc., while others disagreed. Lecturers affirmed that there were observable changes in the individual abilities as a result of the CPD programs attended. The participating lecturers think that teaching experience will help lecturers more and they also reported that there are not enough in-service activities/opportunities available for lecturers in the tertiary institutions in Anambra State.

Reflecting on lecturers' views regarding the facilitators of CPD activities in relation to the content and design of CPD activities, most lecturers agreed that the instructors of CPD sessions were knowledgeable, enthusiastic, and well organized; the learning climate of CPD activities was collaborative, informal, and respectful, and during training sessions, they were given opportunities to share their ideas and experiences with peers, as well as to provide feedback on the CPD activities. Though not a majority, a considerable number of respondents felt that there are some inhibitors of CPD activities which included that CPD activities did not take into account teacher's existing knowledge, experiences, and needs as well as the school and system goals, and that they were not involved in determining the topics and content of CPD activities. Inhibitors like poor planning and poor time management and being forced to attend events they do not see the reason to effects the effectiveness of the PD programs. It's important to develop the culture of being strict and disciplined with time during all events.

Considering the facilitators of CPD activities in terms of the educational climate at school, more than half of the lecturers pointed out that School and faculty administration is supportive of a lecturers' desire to grow professionally, Administrators and deans, and faculty leaders' evaluation reports are very helpful in enabling lecturers to grow professionally, lecturers in my institution can attend any workshops, seminars or courses as they would like, lecturers in my institution have opportunity to work together, observe each other in classroom teaching, and give each other constructive feedback, informal evaluations of my teaching performance from other lecturers, and access to professional publications. Here also, an appreciable number of participating lecturers disagreed with the above items. From the qualitative data, it was noted that lecturer-lecturer support and mutual assistance should be encouraged. Also, lecturers desire sponsorship and financial support for conference 
paper presentations and publications in peer-reviewed journals. Even while the evaluations from participating lecturers were above average, it is important that the institutions under study and in Nigeria put the matters mentioned in the study under consideration.

The conclusions drawn from this study provide areas for consideration for the tertiary institutions under study and other higher institutions as well, when considering the CPD contents, CPD activities that focus on lecturer career development, lecturer-student relationships, and improving school culture and climate. Understanding lecturers' perceptions and views of CPD may be helpful to facilitate and improve the CPD processes for lecturers in Nigeria and other countries.

Recommendations

Based on the findings it has been recommended that

1. As the efficiency of the higher institution system is greatly anchored on the competence of the academic staff which is dependent on their professional development because training and development play a vital role in the efficiency of the organizational system and the effectiveness of every personnel, it is important that lecturers' CPD must be given good attention by the management of the higher institutions.

2. Improved and proper funding schemes for lecturers' CPD activities, research and paper publications, and staff development generally should be taken into great consideration, at same time making research publications one of the major criteria for promotion in order to encourage the lecturers to develop themselves in their area of specialization.

3. Institution management and CPD planners should take into account lecturers' existing knowledge, experiences, and needs when planning CPD activities and programs. CPD activities should be planned with the school and system goals in mind.

4. For a healthy culture and mutual existence, lecturer-lecturer support and mutual assistance should be encouraged and supported.

\section{References}

Abduh, A. \& Rosmaladewi, R. (2018). Promoting Intercultural Competence in Bilingual Programs in Indonesia. SAGE Open, 8(3), 1-7.

Adagiri, S. O. (2014). A Comparative Study of Teachers' Continuing Professional Development (CPD) In Nigeria and England: A Study of Primary Schools in Abuja and Portsmouth. Doctoral Thesis. School of Education and Continuing Studies, University of Portsmouth, England.

Adeyemi, T. O. (2011). Impact of information and communication technology (ICT) on the effective management of universities in South-West Nigeria. American Journal of Social and Management Sciences, 2(3), 248-257.

Akomolafe, C. O. \& Belo, F. A. (2019). Academic Staff Training and the Challenges of Accessing TETFund in Southwest Nigerian Universities. Literacy Information and Computer Education Journal (LICEJ), 10(3), 3271-3277.

Akpan, C. P. (2014). ICT Competence and Lecturers' Job Efficacy in Universities in Cross River State, Nigeria. International Journal of Humanities and Social Science, 4(10), 259-266.

Akuegwu, B. A., Nwi-ue, F. D., Etudor-Eyo, E. (2013). Lecturers' Participation in Capacity Building Programmes in South-South Nigeria: Implications for Sustainable Development. Makerere Journal of Higher Education, 4(2), 279 - 292.

Amadi, E. C., \& Promise, A. (2013). Professional development and teachers' academic performance in secondary schools in ETCHE Local Government Area. International Journal of Education and Development, 1(2), 19-23.

Bakare, J., Onah, B. I., Okereke, G. K. O. Capacity Building Needs of Lecturers in E-Teaching for Effective Delivery of Computer and Electrical/Electronic Technology Courses in Tertiary Institutions in Southwestern, Nigeria. International Journal of Applied Engineering Research, 13(11), 8736-8750.

Bennell, P. (2004). Teacher Motivation and Incentives in Sub-Saharan Africa and Asia. Brighton: Knowledge and Skills for Development.

Bennell, P., \& Akypeampong, K. (2007). Teacher Motivation in Sub-Saharan African and South Asia Berk, R A., Berg, J., Mortimer, R., Walton-Moss, B. \& Yeo, T. P. (2005). Measuring the Effectiveness of Faculty Mentoring Relationships. Journal of Academic Medicine, 80(1), 66-71.

Blandford, S. (2000). Managing Professional Development in Schools. Education Management Series, London: Routledge. Researching the Issues. England: DFID.

Carew, A. L., Lefoe, G. E., Bell, M. \& Armour, L. (2008). Elastic Practice in Academic Developers. International Journal for Academic Development, 1-18.

Chism, H. V. N., Gosling, D., Sorcinelli, M. D. (2010). International faculty development: pursuing our work 
with colleagues around the world. In: Herr K, Robertson D, (eds.) A guide to faculty development. JosseyBass, San Francisco, 234-258.

Cook, C. E. (2014). Professional Development for Chinese University Leaders: Collaboration, Not Competition. In Q. Li and C. Gerstl-Pepin (eds.), Survival of the Fittest, New Frontiers of Educational Research, Springer-Verlag Berlin Heidelberg.

Darling-Hammond, L. \& Baratz-Snowden, J. (Eds.) (2005). A Good Teacher in Every Classroom: Preparing the Highly Qualified Teachers Our Children Deserve. San Francisco, CA: Jossey-Bass.

Desimone, L. M. (2011). A primer on effective professional development. Phi Delta Kappan, 92(6), 68-71.

Ekpoh, U. I., Edet, A. O. \& Nkama, V. I. (2013). Staff Development Programmes and Secondary School

Teachers' Job Performance in Uyo Metropolis, Nigeria. Journal of Education and Practice, 4(12).

Falola, H. O. \& Osibanjo, A. O., \& Ojo, S. I. (2014) Effectiveness of training and development on employees' performance and organization competitiveness in the Nigerian banking industry. Economic Sciences, 7 (56), 161-170.

Ferman, T. (2002) Academic professional development practice: What lecturers find valuable. International Journal for Academic Development, 7(2), 146-158.

FME (2014). National Teacher Education Policy. Federal Ministry of Education, the Federal Republic of Nigeria.

Garuba, A. (2007). Continuing Professional Development Environment for Teachers: Models, Institutions and Concerns. Nigerian Journal of Professional Teachers, 1(4), 146-166.

Iyunade, O. T. (2011). Teachers' Continuing Professional Development as Correlates of Sustainable Universal Basic Education in Bayelsa State, Nigeria. An International Multidisciplinary Journal, Ethiopia, 5(4), 161177.

Kambona, S. F. (2019). A review of teachers' professional development in China: A lesson to Tanzanian teachers for $21^{\text {st }}$-century skills. The WCCES Chronicle, 3(1).

Lee, V. S., DeZure, D., Debowski, S., Ho, A. \& Li, K. (2013) Enhancing international collaboration among academic developers in established and emerging contexts: moving toward a post-colonial perspective. International Journal for Academic Development, 18(1), 89-103.

Leibowitz, B., Bozalek, V., Schalkwyk, S. V. \& Winberg, C. (2015), Institutional context matters: the professional development of academics as teachers in South African higher education. Higher Education, 69(2), 315-330.

Muijs, D., Day, C., Harris, A., \& Lindsay, G. (2004). Evaluating Continuing Professional Development: An overview. In C. Day \& J. Sachs (Eds.), International Handbook on the Continuing Professional Development of Teachers. Ballmoor Bucks: Open University Press.

Nabunya, K. 1, Mukwenda H. T. \& Kyaligonza, R. (2019). Professional Development Practices and Service Delivery of Academic Staff at Kampala International University and Kyambogo University. Makerere Journal of Higher Education, 10 (2), 133-143.

Nwaubani, O., Nwokenna, E., Nathaniel, C., Ezema, L. \& Edeh, N. (2016). In-Service Professional Training Needs of Teachers for Effective Implementation of Junior Secondary Social Studies Curriculum in Nsukka Education Zone, Enugu State, Nigeria. European Journal of Social Sciences, 53, 152-165.

Ogunyinka, E. K., Okeke, T. I., Adedoyin, R. C. (2015). Teacher Education and Development in Nigeria: An Analysis of Reforms, Challenges, and Prospects. Education Journal, 4(3), 111-122.

Olelewe, C. J. \& Amaka, E. N. (2011). Effective utilization of information and communication technology (ICT) for sustainable manpower development among computer educators in colleges of education in the southeast geo-political zone of Nigeria. A paper presented at the $24^{\text {th }}$ National Association of Technology Teachers (NATT) on Technical Vocational Education and Training (TVET) for sustainable industrial development in Nigeria between 17th-21st October 2011 at Umunze, Anambra State, Nigeria.

Oyebade, S. A. (2008). Staff development policies, programmes, and facilities for teacher education in Nigeria. Kampala International University Kampala, Uganda.

Ozurumba, C. N., Amasuomo, J. O. (2015). Academic Staff Development and Output in State Universities in South-South Nigeria. Makerere Journal of Higher Education, 7(2), 49-59.

Padwad, A. \& Dixit, K. (2011). Continuing professional development: An annotated bibliography. British Council India. Retrieved Feb 1 from http://www.britishcouncil.org/cpdbiblio.pdf.

Parkes, J. \& Stevens, J. J. (2000). How professional development, teacher satisfaction, and plans to remain in teaching are related: Some policy implications. Research Report 2000-1. Albuquerque, NM: APS/UNM Partnership

Patrick, O. B. (2020). Analyzing the Job Motivation Level of Primary School Teachers in Nigeria. International Journal of Research and Innovation in Social Science (IJRISS), 4(7), 455-463.

Paymaster, L., Lyndon, B., \& Elate, L. M. (2014). The impact of human resource development of academic staff in Nigeria universities: A study of selected Universities in Bayelsa staff of Nigeria. Developing Country 
Studies, 4(24), 82-87.

Rosmaladewi, R., \& Abduh, A. (2017). Collaborative Teaching Cultures of English Lecturers in Indonesian Polytechnics. International Journal of Language Education, 1(1), 20-28.

Rosmaladewi, R., Abduh, A., \& Basri, M. (2020). English Lecturers' Experiences on Professional Development in Indonesian Polytechnics. International Journal of Language Education, 4(2), 314-321.

Roux C. L. and Ferreira G. (2005). Enhancing environmental education teaching skills through in-service education and training. Journal of Education and Teaching, 31(1), 3-14.

Snow-Renner R. and Lauer P. (2005). Standards-based education: Putting research into practice. Insights.

Retrieved

Feb

1

from http://www.mcrel.org/ /media/Files/McREL/Homepage/Products/01_99/prod26_standsynth.ashx.

Suleiman, H. O. (2015). Impact of staff development programmes on the job performance of federal Polytechnic lecturers in Nigeria. Published Ph.D. dissertation. Ahmadu Bello University, Zaria.

Sywelem, M. M. G. \& Witte, J. E. (2013). Continuing Professional Development: Perceptions of Elementary School Teachers in Saudi Arabia. Journal of Modern Education Review, 3(12), 881-898

Thurston, A., Christie, D., Howe, C., \& Tolmie, A. (2008). Effects of continuing professional development on group work practices in Scottish primary schools. Journal of In-service Education, 34(3), 1-30

Udoh-Uwah, O. E. \& Etim, M. E. (2018). Professional Development and Lecturers' Job Effectiveness in Universities in South-South Geo-Political Zone of Nigeria. Journal of Education and Practice, 9(12), 123128.

Ujumadu, V. (2020). ICT: TETFUND empowers 100-Oko Polytechnic staff in Anambra. Retrieved Feb 8 from https:/www.vanguardngr.com/2020/12/ict-tetfund-empowers-100-oko-polytechnic-staff-in-anambra/

UNESCO (2011). World Data on Education (Saudi Arabia) (7th ed.), UNESCO Publisher.

Usman, M. (2006). Enhancing the Quality of Teacher Education in Nigeria: The Need for Information Technology (IT) Fitness among Librarians in Colleges of Education.Paper presented at the National Conference of Teacher Education, University of Abuja

Villegas-Reimers, E. (2003). Teacher professional development: an international review of the literature. UNESCO: International Institute for Educational Planning.

Walters, S., Openjuru, G. (2016). Knowledge engagement and higher education in Africa. UNESCO Report.

Wall, J. (2013). A Framework for Academic Professional Development in Higher Education. Ac conference paper, Waterford Institute of Technology, 1-13

Wati, H. (2011). The effectiveness of Indonesian English teachers' training programs in improving confidence and motivation. International Journal of Instruction, 49(1), 609-629.

Xia, J. G., Gao, X. Y. \& Shen, J. P. (2017) School Autonomy: A Comparison between China and the United States. Chinese Education \& Society, 50(3), 284-305.

$\mathrm{Xu}, \mathrm{H}$. (2015). The development of teacher autonomy in collaborative lesson preparation: A multiple-case study of EFL teachers in China. System. 52. 139-148.

Yusuf, M. A., Afolabi, F. O., \& Loto, A. B. (2013). Appraising the role of information communication technology (ICT) as a change agent for higher education in Nigeria. International Journal of Educational Administration and Policy Studies, 5(8), 177-183. 